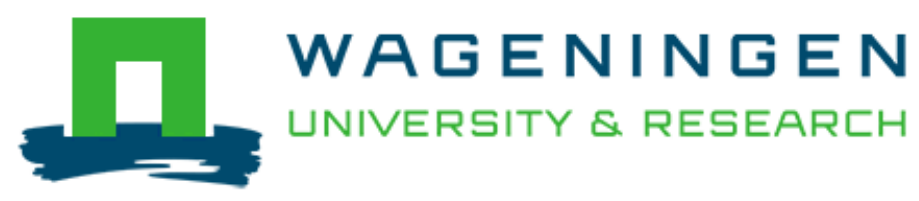

Financing marine conservation tourism: Governing entrance fees in Raja Ampat, Indonesia

Atmodjo, E., Lamers, M. A. J., \& Mol, A. P. J.

This article is made publically available in the institutional repository of Wageningen University and Research, under article $25 \mathrm{fa}$ of the Dutch Copyright Act, also known as the Amendment Taverne.

Article $25 \mathrm{fa}$ states that the author of a short scientific work funded either wholly or partially by Dutch public funds is entitled to make that work publicly available for no consideration following a reasonable period of time after the work was first published, provided that clear reference is made to the source of the first publication of the work.

For questions regarding the public availability of this article, please contact openscience.library@wur.nl.

Please cite this publication as follows:

Atmodjo, E., Lamers, M. A. J., \& Mol, A. P. J. (2017). Financing marine conservation tourism: Governing entrance fees in Raja Ampat, Indonesia. Marine Policy, 78, 181188. DOI: $10.1016 /$ j.marpol.2017.01.023

You can download the published version at:

https://doi.org/10.1016/j.marpol.2017.01.023 


\title{
Financing marine conservation tourism: Governing entrance fees in Raja Ampat, Indonesia
}

\author{
Ery Atmodjo ${ }^{\mathrm{a}, \mathrm{b}}$, Machiel Lamers ${ }^{\mathrm{a}, *}$, Arthur Mol $^{\mathrm{a}}$ \\ a Environmental Policy Group, Wageningen University, The Netherlands \\ ${ }^{\mathrm{b}}$ University of Papua, Manokwari, Indonesia
}

\begin{abstract}
A B S T R A C T
Worldwide, the growth of marine tourism is creating opportunities for financing marine protected areas (MPAs), but what these financial arrangements look like and how they can be governed at larger scales, and in equitable and transparent ways, is unclear. This paper examines the governance arrangement of two regionwide successive entrance fee systems established since 1997 in Raja Ampat, Indonesia, to finance a network of MPAs delineated under the auspices of two big international non-governmental organizations (NGO), namely Raja Ampat Entrance Fee and Raja Ampat Ecosystem Service Stewardship Fee. These two successive entrance fee systems can be viewed as payment for environmental services (PES) arrangements. The PES-like entrance fee arrangements improved in terms of participation, transparency and equity. In the second scheme, local communities in Raja Ampat were involved in the design of the disbursement of the community fund, and the criteria for disbursement became more clear and transparent. However, in both schemes there is no clear connection between the distribution of the funds and activities that improve environmental services provision (conditionality). In addition, the latter scheme is still facing equity challenges as some communities with customary rights over marine tourism hotspots are asking for additional user-fees from tourists and tourism operators.
\end{abstract}

\section{Introduction}

Over the last three decades, the designation of marine protected areas (MPAs) worldwide has increased and proliferated, but not reached a similar coverage compared to terrestrial protected areas $[11,38]$. Generally, MPAs aim at the protection and maintenance of ecological values and biodiversity conservation in response to increasing marine activities and global environmental changes that lead to the degradation of marine resources [12,31,34]. Generally, it is seen as the responsibility of the government to designate and manage MPAs [11]. However, government funding for managing the increasing number of MPAs is regarded insufficient [42], and lack of monitoring and enforcement makes it difficult to achieve conservation objectives. With $70-80 \%$ of MPAs worldwide being labelled as 'paper park' [12], the dependency on only government funding to achieve marine conservation is therefore considered problematic [42].

Marine tourism is widely regarded as a strategy to overcome the shortfall of finance for effective management of MPAs, for example through user payments and licensing fees [12,38,42], philanthropic donations [31], or private conservation mechanisms [11]. Various studies have examined the opportunities and limits of tourist entrance fees for financing MPAs, for example with regard to the tourists' willingness to pay (WTP) entrance fees to cover management costs $[8,16,29]$, the mixed attitudes of tourists toward entrance fees and their structure [7], and the impact of entrance fees on visitation [42]. While most of the mentioned literature focuses on the tourist side, the literature on the governance side of MPA entrance fee arrangements is rather scarce, particularly regarding their longer term ability to deliver tangible results for the stakeholders and communities involved.

A recent and relevant perspective is provided by the literature on payments for environmental services (PES). PES was invented as a market approach to overcome environmental externality problems $[18,28,41]$. Implementation of PES is aimed at providing incentives to those who manage or have control over natural resources to make decisions that maintain positive or reduce negative externalities through direct market transactions. Those who bear the cost of generating a particular environmental service should be compensated by those who benefit from the service. The most widely used conceptualization of PES describes it as: (1) a voluntary transaction between (2) at least one service provider who must secure its provision and (3) at least one service buyer for (4) environmental service (ES) (5) if and only if the service provider secures the provision of the

\footnotetext{
* Corresponding author.
} 


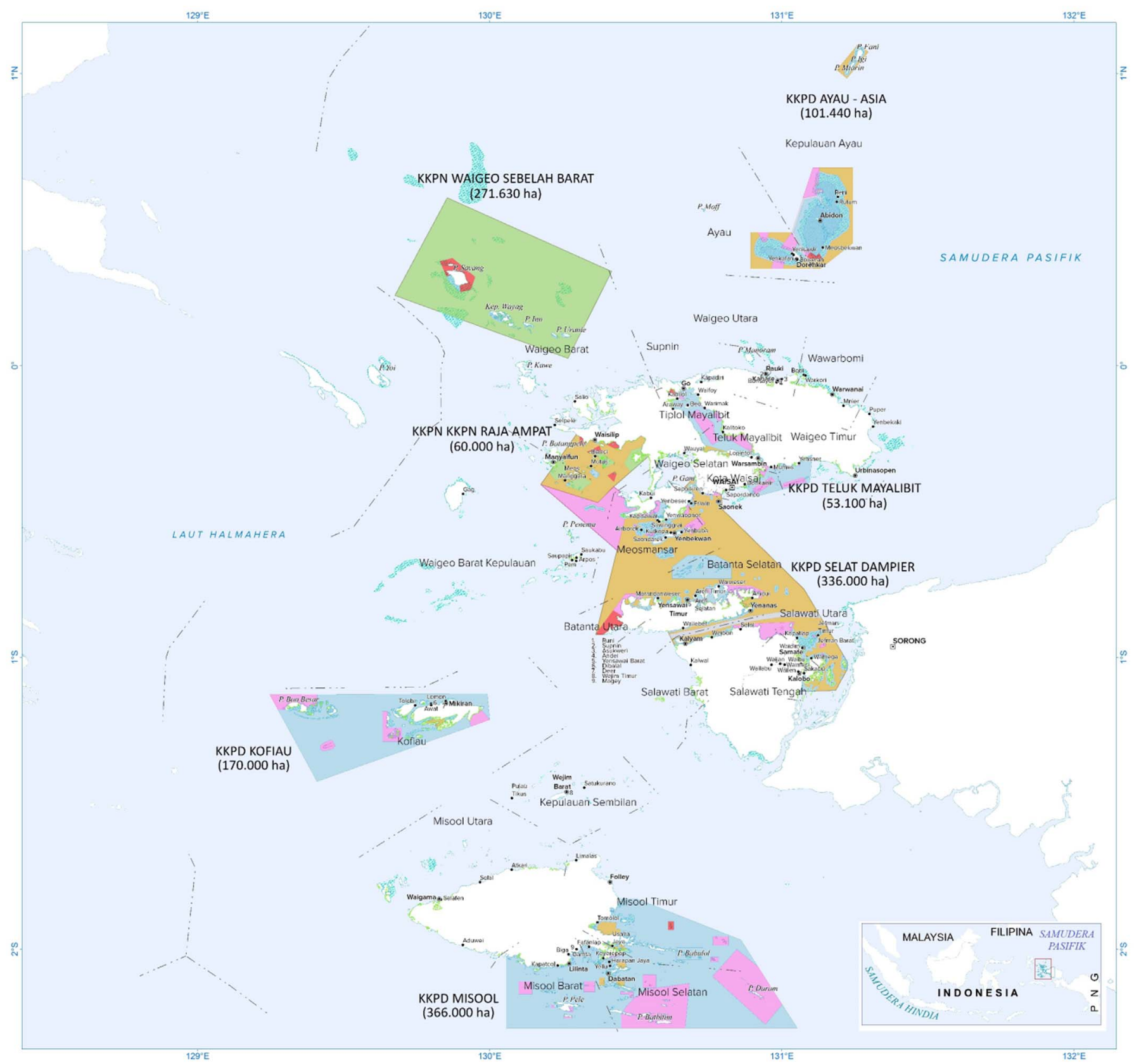

Fig. 1. Map of the case study area (adapted from [15]).

environmental service (conditionality) [44]. Most PES programs worldwide are implemented for terrestrial environments [20], with common environmental services being carbon sequestration and storage, biodiversity conservation, watershed protection, and landscape beauty [44], administered through different market mechanisms, such as ecotourism, watershed services, hunting permits and green commodities $[10,19]$. There is great potential of PES arrangements for conserving coastal and marine environmental resources, including in commercial fishing, aquaculture and marine tourism [14], but the current literature is limited.

Lessons from the implementation of PES arrangements in terrestrial environmental settings suggest a number of design principles for successful PES governance arrangements. First, the design of the PES arrangement needs to be clear on who the buyer is, what environmental service is delivered (conditionality) and how the payment mechanism works. Second, direct transactions between buyers and sellers are favoured over payment mechanisms aided by intermediaries [28], as direct payments enhance transparency. Third, payment mechanisms need to represent an equitable distribution of costs and benefits in the eyes of the participating groups [1]. Fourth, it is important for local communities, in whose territories the PES arrangement is set, to benefit, for example by income accrued to local communities, job creation, or other forms of livelihood enhancement [17]. Conceptually, these design principles of PES arrangements resonate with the environmental governance literature in understanding how governance arrangements can be steered in ways that are seen by those involved as effective, participatory, equitable and transparent [23]

This paper aims to contribute to our understanding of policy change in financing marine conservation tourism by analysing the Raja Ampat entrance fee as a PES governance arrangement. Even though there is no explicit statement about a particular paradigm on which the Raja Ampat entrance fee was developed, it shows a relationship with the concept of ecosystem services (ES) - ecosystem processes, functions, organization or structure utilized or consumed by human being for 
their wellbeing $[13,35]$, where the fund paid by tourists will be used to maintain ES. Therefore, in this paper we will analyse the evolvement of the Raja Ampat entrance fee as a PES arrangement.

The designation of the [30] opened opportunities for marine resources to be managed locally [40]. The Indonesian central government policy regarding marine conservation gave way for the establishment of locally managed MPAs as part of sustainable marine resource use [33]. This has led to the establishment and management of six MPAs developed under the auspices of two international non-governmental organizations (NGOs) involved in nature conservation, i.e. Conservation International (CI) and The Nature Conservancy (TNC). The management of these MPAs has recently been transferred to the local authorities. In attempting to ensure economic benefits from tourism to local communities, in 2007 the Raja Ampat Regency government established a tourist entrance fee system [26]. This scheme encountered a range of governance challenges regarding the management and disbursement of the funds generated, and was revised in 2015, after being in effect for eight years.

This paper aims to understand the extent to which the revision of the entrance fee system of Raja Ampat resulted in a better design from a PES perspective, to identify the governance challenges of the arrangement with regards to transparency and equity, and to generate insights in the global challenge of financing marine conservation.

The next two sections present Raja Ampat and the methodology used in this study, including a description of the case study area, the data collection and the analysis. Subsequently a brief historical account is given of the establishment of the entrance fee scheme and the challenges faced by the Raja Ampat, followed by an analysis of the two schemes. The article closes with conclusions.

\section{Raja Ampat marine conservation}

The research is set in Raja Ampat, an archipelago in West Papua Province, Indonesia (see Fig. 1), consisting of four large islands and more than 600 small islands and atolls. The population of Raja Ampat is relatively small, but it hosts diverse ethnic groups, including indigenous Melanesian and long time settlers from adjacent areas [2]. The area draws global attention because of its richness in marine biodiversity $[2,26,27]$. Following the decentralization policy of the Indonesian state [39,6], Raja Ampat was established as a regional administrative unit in 2002, which became operational in 2005 [30]. The fishery sector became a development priority during the first 5 years of the new Regency, while marine tourism became more important in the government development program since 2010 [4]. The potential benefits of the rich marine biodiversity for marine tourism suffered from illegal and destructive fishing practices, both by local community members as well as by outsiders $[25,26]$. Threats to marine biodiversity in the area [26] encouraged marine conservation efforts involving various international NGOs [33], such as Conservation International (CI) and The Nature Conservancy (TNC). A network of 6 MPAs was designated under auspices of $\mathrm{CI}$ and TNC, covering a total of 1.113 million hectares, scattered from the north part to the south part of Raja Ampat [33] (see Fig. 1). In addition, from 2005 till 2015 the World Bank coral reef rehabilitation and management program (COREMAP II) funded and implemented various projects in the area.

In the wake of these international conservation initiatives marine tourism activities have been growing over the last decade [26,37]. Raja Ampat is considered a tourism hot-spot, well known for its incomparable coral reef diversity [21]. Tourism businesses increased considerably in the last decade, with around 14,000 visitors in 2015, mostly international tourists. Permanent yearly operation permits for liveaboards (tourist vessels) is limited by the Regency to 40 vessels, permits for resorts outside the capital city is limited to 20, while homestays (local accommodations) have grown to more than 40 units. Raja Ampat's tourist attractions range from coral reef SCUBA diving and snorkelling, to bird watching, kayaking and scenery sightseeing. Most of these tourist attractions are located in MPAs, with the majority in the Selat Dampier MPA, while one of the most iconic attractions, Piaynemo, is located outside any MPA (see Fig. 1).

To ensure the benefit of marine conservation tourism to the local communities, a tourism entrance fee system has been developed by the local authority, which has undergone a number of remarkable changes since its inception. The Raja Ampat tourist entrance fee scheme thereby provides an excellent context for exploring governance arrangements of financing marine conservation tourism. The case study of Raja Ampat allows us to carry out an in-depth exploration of these governance challenges in a particular temporal and spatial setting $[22,45]$.

\section{Methodology}

\subsection{Case study}

To achieve the objective of this paper, i.e. understanding policy change in financing marine conservation tourism, a qualitative case study research design was chosen [22]. Raja Ampat as case study area provides different characteristics compared to other PES schemes outlined by most literatures. Most PES schemes are implemented on single delineated terrestrial areas, with less heterogeneous local communities, and few stakeholder organizations involved [3,9,17,23]. Raja Ampat PES-like scheme is implemented in the whole Regency covering around 4 million hectares area of archipelago where 117 villages and 6 MPAs are scattered across the Regency. Although it is has only around 56,000 inhabitants, the local communities of Raja Ampat consist of four tribes. Each of the four tribes consists of several sub tribes [4]. This raises different challenges in the implementation of the PES-like scheme compared to similar schemes in other settings.

\subsection{Data collection and analysis}

Fieldwork was carried out between October 2014 and January 2015. Three qualitative data collection techniques were used in this research, i.e. in-depth interviewing, participatory observation and document analysis [22,32]. In-depth interviewing was used to obtain information regarding the ideas, roles, resources and experiences of actors involved in, as well as the rules and process that lead to, the entrance fee arrangements [22,32]. Twenty two in-depth interviews were held with individuals and small groups, involving 19 respondents in total, identified by using the snowballing technique [5]. Key players were approached first, in this case the head of the Tourism Office of Raja Ampat and the NGO representative who was involved deeply in conservation in Raja Ampat. They were asked to suggest other relevant individuals, which were then selected as respondents. Additional respondents were found in this way, until no new information was found from the last respondents. Respondents typically included those in leading positions in marine conservation tourism governance, both in the present and during the past two decades, such as government directors and staff (A), NGO officers and staff (B), community leaders (C) and tourism operators (D). Most interviews were recorded and subsequently transcribed verbatim. Second, during fieldwork we participated in a number of activities and meetings as participant observer, and functioned as a consulting expert in the redesign of the mechanism to disburse collected entrance fees. Observations of discussions and interactions between various actors during such meetings resulted in detailed notes and insight. Thirteen participants of different meetings were identified providing information and opinions relevant to this paper, hence they are also regarded as respondents (Table 1). Third, document analysis was conducted to obtain information from a range of secondary sources collected before and during the fieldwork, such as reports (published and unpublished), maps, minutes of meetings, meeting presentations and websites.

The interview data formed the starting point for the analysis. 
Table 1

List of respondents.

\begin{tabular}{|c|c|}
\hline Respondent & Affiliation \\
\hline $\mathrm{A}_{1}$ & Tourism office \\
\hline $\mathrm{A}_{2}$ & Tourism office \\
\hline $\mathrm{A}_{3}$ & Tourism office \\
\hline $\mathrm{B}_{1}$ & NGO \\
\hline $\mathrm{B}_{2}$ & NGO \\
\hline $\mathrm{B}_{3}$ & NGO \\
\hline $\mathrm{B}_{4}$ & NGO \\
\hline $\mathrm{B}_{5}$ & NGO \\
\hline $\mathrm{B}_{6}$ & NGO \\
\hline $\mathrm{C}_{1}$ & Local community leader \\
\hline $\mathrm{C}_{2}$ & Local community leader \\
\hline $\mathrm{C}_{3}$ & Local community leader \\
\hline $\mathrm{C}_{4}-\mathrm{C}_{7}$ & Local community leader (FGD) \\
\hline $\mathrm{C}_{8}-\mathrm{C}_{10}$ & Local community leader (FGD) \\
\hline $\mathrm{C}_{11}-\mathrm{C}_{13}$ & Local community leader (FGD) \\
\hline $\mathrm{C}_{14}$ & $\begin{array}{l}\text { Member of provincial house of representative/Leader of local } \\
\text { NGO }\end{array}$ \\
\hline $\mathrm{D}_{1}-\mathrm{D}_{3}$ & Board member of homestay association (FGD) \\
\hline $\mathrm{D}_{4}$ & Homestay operator \\
\hline $\mathrm{D}_{5}$ & Resort operator \\
\hline $\mathrm{D}_{6}$ & Resort operator \\
\hline $\mathrm{D}_{7}$ & Resort operator \\
\hline $\mathrm{D}_{8}$ & Liveboard operator \\
\hline $\mathrm{D}_{9}$ & Liveboard operator \\
\hline $\mathrm{D}_{10}$ & Liveboard operator \\
\hline $\mathrm{D}_{11}$ & Liveboard operator \\
\hline $\mathrm{D}_{12}$ & Liveboard operator \\
\hline $\mathrm{D}_{13}$ & Speed boat operator \\
\hline $\mathrm{D}_{14}$ & Speed boat operator \\
\hline $\mathrm{D}_{15}$ & Speed boat operator \\
\hline
\end{tabular}

Interviews were coded with an eye on the governance challenges faced and the PES lessons presented in the introduction. The interview findings were further substantiated, cross-checked and triangulated using observation notes and documentation.

\section{The Raja Ampat entrance fee}

\subsection{Establishment}

The increasing involvement of foreign and non-indigenous people and organizations in the development of tourism and marine conservation fuelled the local perspective on outsiders benefitting more from marine resources than the local community of Raja Ampat [25]. This has encouraged local communities holding customary rights over marine resources in popular tourism sites to collect visitor fees from tourists and tourism business to access these sites. While these informal local entrance fees made sense from a community perspective, this practice was seen as unfavourable by the conservation NGOs and tourism businesses $\left(B_{2}-B_{4}, D_{5}-D_{11}\right)$.

In 2007, the Regency government of Raja Ampat passed a regula- tion that created the Raja Ampat entrance fee, partially to deal with the problem of communities collecting entrance fees to their sites, and also to generate revenue to cover the costs of marine conservation. Subject to the regulation were visiting tourists and researchers, both international and Indonesian, except Raja Ampat residents. An international visitor would pay $\mathrm{Rp} 500,000$ (equivalent to US\$ 40), while an Indonesian visitor paid $\mathrm{Rp} 250,000$, for a one year permit to visit tourist sites or conduct research in Raja Ampat Regency. Visitors would be given a proof of payment and a souvenir. Rp 150,000 from each of


( $30 \%$ of entrance fee respectively) went to the general revenue of the Regency. The rest of the revenue was divided into three allocations: $20 \%$ to cover the operational cost of managing the revenue of the entrance fee system, $40 \%$ for the conservation fund, and the remaining $40 \%$ for the community fund.

The so-called non-retribution fund management team (fund management team hereafter) was established to manage the revenue of the entrance fee and was accountable directly to the Regent. The fund management team, led by the director of the tourism office, consisted of a conservation section and a creative economic section. The conservation section was led by a staff member of the COREMAP project, and further included managers of $\mathrm{CI}$ and TNC. It was appointed to develop proposals to the fund management team and organizing the disbursement of the fund for conservation efforts. The creative economic section, led by an officer of the tourism office and including a homestay operator and a liveaboard operator, was appointed with the task of advising the fund management team and organizing the disbursement of the fund for activities aimed at improving local livelihood. Revenue from the entrance fee was allocated to the general revenue of the Regency, to conservation efforts (e.g. rule enforcement in MPAs, ecological monitoring of coral reefs), to a community fund to enhance local livelihood, and to the costs of the fund management team.

The fund management team was not guided by specific rules or any standard operating procedure (SOP) that would describe the working procedures of the fund management team and the disbursement mechanism of the revenue to the community or to conservation efforts $\left(\mathrm{A}_{2}\right)$. Interviews, however, revealed that the revenue of the entrance fee was initially used to provide food supplements for children under 5 years old in 75 villages, and was later on used for funding projects proposed by local communities or NGOs $\left(\mathrm{A}_{1}, \mathrm{~A}_{2}\right)$. Project proposals submitted by local communities were collected by the secretary, and subsequently analysed by the fund management team for approval.

\subsection{Challenges}

When analysing the Raja Ampat entrance fee in line with the PES principle, it becomes clear that the entrance fee was applied to international and domestic tourists and researchers, who can be identified as ecosystem service (ES) buyers (Raja Ampat Regency Regulation 64, 2007; 65, 2007). However, the supply side of the

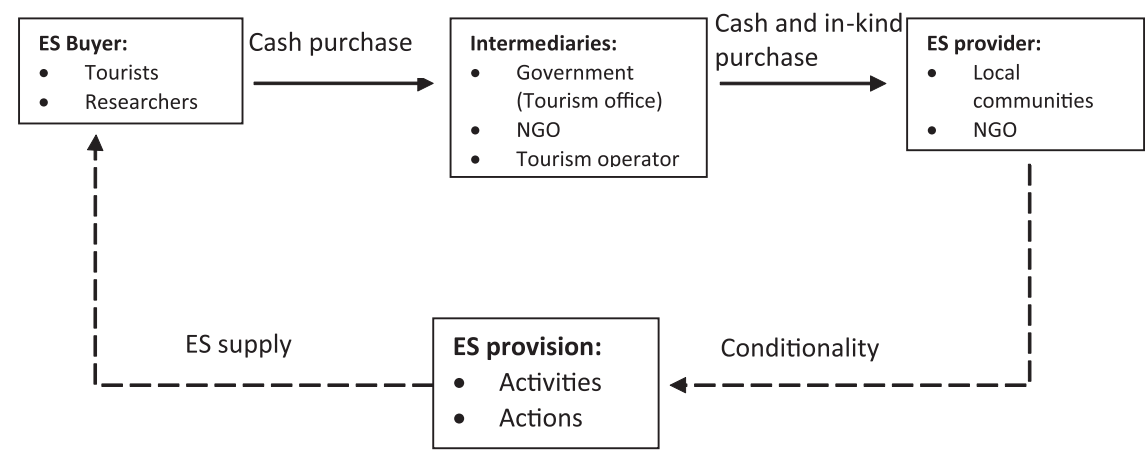

Fig. 2. Overview of Raja Ampat Entrance Fee through PES framework. $\longrightarrow$ Clear arrangement; $-\longrightarrow--\rightarrow=$ Unclear arrangement. 
ecosystem service was not clear-cut (Fig. 2). The supply side of the ecosystem service was identified by analysing the role of actors in the field, both in interviews and in policy documentation (Regulation 65/ 2007). The Regency and local communities can be seen as principle ES sellers, as the payment granted access to environmental resources in their region and part of the revenue is accrued by community members whose community project proposals were approved. Further, the analysis of revenue disbursement revealed that some proposals were submitted by MPA staff who worked for TNC and CI for conservation efforts conducted in MPAs managed by CI and TNC. This positioned CI and TNC as ES sellers as well, because their conservation activities were partly financed by revenues from the entrance fee. At the same time, the members of the fund management team, including the NGOs and a local tourism operator, can be regarded as intermediaries in the ecosystem service purchasing process, as they disbursed the entrance fee to the recipients. It has been argued that this mixing of roles on the supply side has affected the transparency of the revenue distribution process.

As the entrance fee system and the fund management team were established through government regulation, the revenue collected was considered government funds, to be managed according to central government financial regulations and subjected to governmental financial audits. An interview with the secretary of the fund management team revealed that the lack of operating procedures and mechanisms for disbursement had made the team very cautious in money disbursement, in order to avoid violations of government regulation. This resulted in the accumulation of the funds in the account of the fund management team and a very low disbursement rate. Respondents from NGOs mentioned that with respect to the objective set during its establishment the entrance fee system was considered ineffective $\left(B_{3}\right)$. This has led to disappointment among the local community who had refrained from illegal and destructive fishing. Furthermore, it turned out that the entrance fee system had not stopped some villages close to popular sites from collecting their own visitation fee from tourists and tourism operators. Two tourism liveaboard operator $\left(\mathrm{D}_{1}, \mathrm{D}_{1}\right)$ pointed out that: “..it is as if the situation has been back to the beginning..”. Two village officers $\left(\mathrm{C}_{2}, \mathrm{C}_{3}\right)$ acknowledged that they have issued a Village Regulation to collect tourist fee, while a secretary of another village $\left(\mathrm{C}_{1}\right)$ implicitly acknowledged that they were also collecting fees from tourists by saying: "...we will stop asking fees if the community fund is distributed to our village."

Analysis of the disbursement mechanism of the revenues revealed that there was no specific ES provision required by the recipient through the fund management team. The idea was mentioned that payments to local communities were made in an attempt to encourage them to preserve the marine and coastal environment $\left(A_{1}, A_{2}, B_{1}-B_{4}\right)$. Growth of local tourism businesses funded by revenue from the entrance fee was assumed to increase boat traffic that can help in stewardship of the surrounding environment $\left(B_{3}\right)$. However, no arrangement related the payment to actors that improve the environmental quality and to the kind of conduct necessary. In consequence, the conditionality of the PES could not be monitored or assured.

In an interview about the design and implementation plan of the new entrance fee system, a resort operator $\left(\mathrm{A}_{1}\right)$ voiced the disappointment of the local community:

"There was disappointment in Misool on the disbursement of the community fund in the past by evenly distributing the fund to all villages. Tourist destination villages which were visited more by tourists disagree with the scheme and think it is illogical"

According to community fund distribution data, the first distribution of revenue from the entrance fee was made in 2010, in the form of healthy food supplements for children under 5 years old. The food supplements were distributed evenly to 75 villages. The implementation was made in collaboration with the health units of the respective villages. Since 2011, the fund was used to finance proposals submitted by local communities to develop tourism business and to conduct conservation activities in some villages. The distribution of healthy food supplements was discontinued. It is clear that the idea of resort operator $\mathrm{A}_{1}$ mentioned above does not completely match the revenue distribution process, since the community and conservation fund were distributed based on proposals submitted to the fund management team instead of being evenly distributed among all villages. However, the distribution did reflect challenges in transparency, equity as well as conditionality.

\subsection{Revisions}

In 2014, changes in regulation from the Regency brought a range of modifications to the arrangement of the entrance fee system (Regent Regulation 18/2014). First, the responsibility for managing the tourist entrance fee was transferred from fund management team to UPTDKKPD, a local authority under the Marine and Fishery Office, whose primary responsibility is the management of the MPA network. This meant that the Regency retained a prominent role in the management of the scheme. Second, the entrance fee system was officially renamed ecosystem service stewardship fee, called stewardship fee hereafter. Third, parallel with the transfer of responsibility changes in the annual entrance fee rates took place, increasing it to $\mathrm{Rp} 1,000,000$ for international and Rp 500,000 for Indonesian visitors. Fourth, under the new scheme the largest share of the fund is allocated to cover operational and non-operational costs of managing the MPA network, while $\mathrm{Rp} 1.5$ billion per year will be allocated for the community fund. The contribution of international tourists to the general revenue of the Regency was doubled to Rp 300,000 per visitor, while domestic tourists' contribution remained at $\mathrm{Rp} 75,000$ per visitor. Hence, $70 \%$ of the revenue from international tourists and $85 \%$ of the revenue from domestic tourists will be managed by UPT-KKPD to cover operational and non-operational costs, after deduction of Rp 1.5 billion for the community fund.

As more than $70 \%$ of the revenues from the stewardship fee will be used by UPTD-KKPD in managing the MPA network, UPTD-KKPD is identified as the central ES seller in the new arrangement. Since regulation on the establishment of UPTD-KKPD also incorporate NGOs as partners of the MPA network management, they also play a role as the ES sellers. The provision of $\mathrm{Rp} 1.5$ billion per year for the community fund puts the community in a ES seller position as well.

The strategic business plan of UPTD-KKPD outlined four strategic programs, namely institutional enhancement, MPA network management, livelihood improvement of local communities around MPAs, and monitoring and evaluation. An important activity in the implementation plan of the strategic programs is stewardship patrol, which according to the business and budget plan absorbs $67 \%$ of on site management costs of MPAs. Minimum outputs of stewardship patrol, as well as activities of other strategic programs are clearly stated in the plan. Rangers of the MPA authority are required to conduct marine patrols in the MPAs twice a week, involving the community surveillance group consisting of four villagers. Standard operating procedures for implementation of planned activities were also developed. A supervisory and audit body was established in the organizational structure of UPTD-KKPD, to monitor revenue utilization from the stewardship fee. This arrangement shows a potentially strong conditionality of ES payment.

Standard operating procedures for disbursement of the community fund were also established. The process leading to the establishment of the standard operating procedures consisted of two main steps, conducted under auspices of CI, TNC and Starling Resources (SR), a management consultancy firm focused on conservation under Bird Head Seascape (BHS) partnership. The first step was a review of the previous entrance fee system and community consultancy. Community consultancy consisted of in-depth interviews with relevant government officers, tourism operators, as well as local leaders to obtain possible 
designs for allocation and disbursement. Three focus group discussions (FGD) were then conducted involving village community leaders of villages around MPAs to generate opinions and advice regarding the design of allocation and disbursement of the community fund. The selected design of allocation and disbursement of the community fund were then brought to the second step, a formal procedure for establishment of government regulation called public consultancy, involving relevant heads of governmental institutions, members of the house of representatives of the Regency, and local community leaders. The approved allocation and disbursement mechanism was then communicated to the villages in a series of FGDs.

The steps taken to create the fairly complex design of the mechanism of community disbursement are expected to improve transparency. The community fund can only be disbursed based on proposals submitted by village governments or village community groups, and which are approved by the village head, village representatives and community leaders. However, the design of community fund allocation is also quite complex, since many factors have to be considered in the allocation. Village location within MPAs, tourist visitation, and customary rights over marine resources are important factors, according to community respondents $\left(\mathrm{C}_{4}-\mathrm{C}_{13}\right)$. It is common in Raja Ampat that tribes or sub-tribes with acknowledged customary rights may live in different villages away from the sites. Another issue frequently pointed out is that even though tourists are visiting particular areas, Raja Ampat itself is seen as trade mark meaning that all villages of Raja Ampat deserve community fund allocation. Local tourism operators, such as the homestay association, also requested involvement in the community fund allocation and disbursement. Based on the factors mentioned previously, the community fund is divided into two parts, i.e. Rp 75 million (5\%) is allocated for small grants for Regency wide local NGOs, while the remaining part (Rp 1.425 billion) is allocated for the village-based community fund. According to Regency Regulation $18 / 2014$, the community fund is eligible only for conservation activities, economic improvement and social affairs of village governments or community groups.

The allocation design of the village community fund is progressive, in the sense that villages with more attributes in relation to MPAs and more tourist visitation will receive more funding. To accommodate the customary rights issue, villages recognized as having customary rights of marine resources in MPAs and tourist destination villages are eligible for these categories. In order to encourage villages adjacent to MPAs to support conservation efforts, they are designated as buffer villages in the allocation design. The resulting village-based community fund allocation design is depicted in Table 2.

Among villages that have one or more attributes in relation to MPAs and tourist visitation, the tourist visited village category is allocated the smallest share of the community fund, while villages within MPAs that are also visited by tourists are allocated the highest share. However, there is no village recognized as being visited by tourists and located outside or not adjacent to an MPA. Therefore, the allocation of community funds to villages that have one or more attributes ranged from $\operatorname{Rp} 13,280,000$ (a buffer village) to Rp 18,750,000 (village within
MPA visited by tourists). While the allocated fund for villages that do not have any attribute in relation to MPA or tourists visitation is very small ('other villages'), the funds for other categories of villages are fairly similar.

Despite the clear allocation and disbursement mechanism of the community fund, the conditionality is less clear. The community fund disbursement is subject to the condition that proposals must be contributing to conservation or community livelihood. However, the extent to which activities funded by the community fund are actually contributing to ES supply is still unclear, as there is no contractual arrangement that requires ES provision upon ES payment. The idea that the community fund disbursement is expected to encourage community involvement in conservation efforts is adopted in the new scheme (see Fig. 3 for a graphical overview of the stewardship fee).

\subsection{Remaining challenges}

Despite the increased clarity of the Raja Ampat stewardship fee in terms of the PES principle, also this arrangement still faces some challenges. First, although allocation of the community fund seemed to be equitable, the funds are very small for a village. Resort operators $\left(D_{6}-D_{7}\right)$ mentioned in a meeting that the community of Selpele, recognized by other communities as having customary rights of Wayag island, even though Selpele is about one hour by speed boat, is still asking for Rp 1 million fee per boat presumably because it is the icon of Raja Ampat marine tourism. The revenue from this extra fee is expected to be much more than the community fund allocated to them. Saporkren village implemented village regulation asking for a retribution of Rp 50,000 per tourist and Rp 100,000 per boat $\left(C_{3}\right)$. During a dissemination FGD $\left(\mathrm{C}_{4}-\mathrm{C}_{13}\right)$, some community leaders asked for possibilities to pass regulation for collecting tourism retribution from tourists and boats visiting the village and tourism spots around the village. They saw this as an opportunity to benefit from tourism, as they have refrained from engaging in destructive fishing methods which have made the growth of marine conservation tourism possible.

Second, the concept of 'tourist visited village' is also quite unclear, as it is only based on expectation. Sales reports cannot be used for the designation of a tourist visited village because most tourists visit more than one village and dive/snorkelling spots. Liveaboards trips usually take seven to ten days, consisting of around 30 dives in different spots around Raja Ampat. Disputes about the tourist visited village status may diminish the effectiveness of the arrangement.

Third, the community fund disbursement mechanism is designed in such a way that the in-kind payment, i.e. contributions in the form of goods and programs instead of cash, is delivered to villages so that the community receives the full amount of the fund allocated. Distributing the community fund to 117 villages in the vast marine area of Raja Ampat is costly. In some cases, the transaction costs involved in delivering the community fund distribution can be higher than the fund allocated to a particular village.

Fourth, concerns regarding the equity of the arrangement in relation to customary rights were also revealed during the dissemina-

Table 2

Village-based community fund allocation per year (2015).

\begin{tabular}{|c|c|c|c|c|c|}
\hline & Base allocation (Rp) & $\begin{array}{l}\text { Tourism village allocation } \\
\text { (Rp) }\end{array}$ & $\begin{array}{l}\text { Conservation village allocation } \\
\text { (Rp) }\end{array}$ & $\begin{array}{l}\text { Buffer village allocation } \\
\text { (Rp) }\end{array}$ & $\begin{array}{l}\text { Total allocation (Rounded) } \\
\text { (Rp) }\end{array}$ \\
\hline Village within MPA & $2,564,103$ & - & $12,019,231$ & - & $14,590,000$ \\
\hline Tourist visited village & $2,564,103$ & $4,116,667$ & - & - & $6,680,770$ \\
\hline Buffer village & $2,564,103$ & - & - & $10,714,286$ & $13,280,000$ \\
\hline $\begin{array}{l}\text { Village within MPA+ tourist } \\
\text { visited village }\end{array}$ & $2,564,103$ & $4,116,667$ & $12,019,231$ & - & $18,750,000$ \\
\hline $\begin{array}{l}\text { Buffer village }+ \text { Tourists visited } \\
\text { village }\end{array}$ & $2,564,103$ & $4,116,667$ & - & $10,714,286$ & $17,450,000$ \\
\hline Other village & $2,564,103$ & - & - & - & $2,565,000$ \\
\hline
\end{tabular}




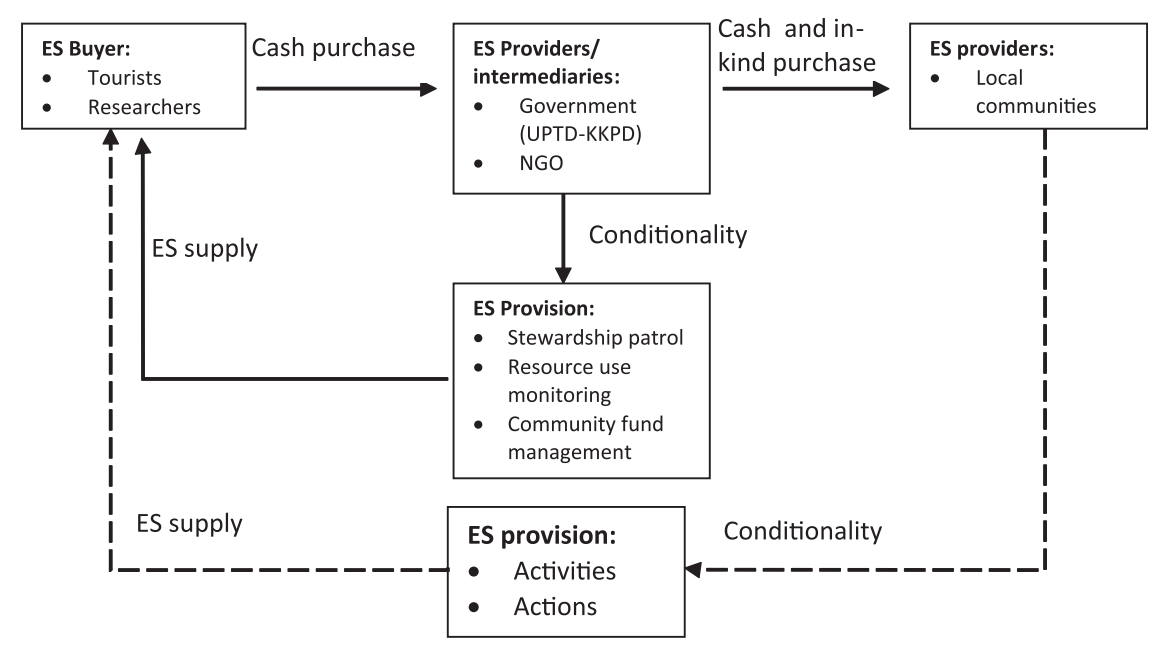

Fig. 3. Overview of Raja Ampat Stewardship Fee using a PES framework. $\longrightarrow$ Clear arrangement; $-ー ー ー-$ Less clear arrangement.

tion meetings. For example, customary ownership of uninhabited tourism spots in an MPA are sometimes held by owners residing in a village outside the MPA. Also, villages often simply do not know whether or not their village is located within an MPA. In order to accommodate customary rights in the scheme, villages in which the customary owners of MPA resources reside is considered a village within an MPA for community fund disbursement purpose. Challenges still exists, however, as conflicts on customary ownership over natural resources is increasing since the emergence of marine tourism [37].

\section{Conclusion}

This paper explored the opportunities of using tourism for financing marine conservation from a PES perspective. More specifically we analysed the governance challenges and implementation dynamics of the region-wide entrance fee system in Raja Ampat, Indonesia. The Raja Ampat entrance fee system can be seen as a state-run PES scheme because the government is the main actor in both arrangements. It is the first of its type and the only scheme currently in effect in Indonesia. In general, this paper concludes that the weaknesses of the previous entrance fee system, when analysed with the design principles of effective PES arrangements, were only partially addressed.

First, our analysis reveals how recent changes in the institutional arrangement of the Raja Ampat entrance fee system have improved participation and transparency. Community groups have been consulted in the process of revising the entrance fee system, and awareness of village communities increased about the opportunities and amounts of disbursement. Moreover, the organization of the entrance fee system has been clarified in terms of organization and procedure, leading to a more direct disbursement. Some interviewees mentioned that they were not aware of the revenue flow from tourism fees, and had no idea on whether or not the tourism fee accrued to their village, even if they actually received community fund from the old entrance fee system. The improved participation and transparency improved the legitimacy of the fee system among various stakeholders. Hence, our study emphasizes and confirms the importance of participation and transparency in multi-actor conservation tourism arrangements, particularly when remote local communities are involved (see also [23]).

Second, the revised entrance fee system resulted in a more clear and equitable arrangement for disbursing community funds to villages in Raja Ampat, based on factors such as the location of the village in or adjacent to an MPA and tourist visitation. However, equity issues remain on the agenda as it is unclear for villages what constitutes a tourist village and tourist visitation is not distributed evenly across the Regency, even among MPAs. Many tourists visit the easy accessible tourism attractions in Selat Dampier MPA, while Ayau-Asia MPA receives almost no tourist visit and Teluk Mayalibit MPA is visited only by very small number of tourists. On the other hand, Piaynemo island, located outside any MPA, is visited by many tourists and has become the new icon of Raja Ampat. The resulting uneven distribution of funds will likely continue to stir equity debates among villages.

Third, this paper argues that conditionality is not only important in relation to environmental service buyers, but also with respect to environmental service sellers. We argue with Wunder $[43,44]$ that conditionality, when environmental service sellers are paid only if provision of environmental services by environmental service sellers is secured, is considered an important but difficult criterion to meet in PES schemes. We have seen how a number of governance challenges that remain unsettled are particularly related to the conditionality of sellers. For example, one condition for customary right owners to receive community funds would be to stop collecting fees from tourists and tour operators, but not all seem to abide by this rule. The case of Selpele shows that the mandate - given to the government by customary resource owners - to manage the marine resource does not automatically transfer all rights along with it. The Dutch colonial period and the precolonial era under the Tidore Sultanate have created a complex and dynamic structure of customary ownership rights over natural resources. Raja Ampat community consists of different ethnicities [4], each with a different status of rights and ownership in relation to natural resources. From an institutional perspective, property and user rights are important elements in the market of environmental services, as those who hold property or user rights can control the use of natural resources that are incorporated in a PES scheme [36,41].

Further, and related, this study has demonstrated that scale matters in PES arrangements, in multiple ways. Contrary to most PES arrangements that work in a relatively small delineated area, the Raja Ampat entrance fee system is a region-wide arrangement implemented to finance a network of six MPAs scattered across the Regency. While this delineation makes sense from a regional institutional perspective, the previous paragraph shows that due to differences in visitation, location and customary rights of local communities it makes more sense to settled payments on a local scale. Hence, various factors should be included in carefully considering scale in PES arrangements.

Finally, as in many PES initiatives [44], payments in Raja Ampat are up front (as prescribed in Regulation 64/2007 and its successor Regulation 18/2014). Monitoring is then necessary to ensure that the recipient of the entrance fee would undertake actions to secure the provision of the environmental service. In order to be able to monitor the extent to which environmental service provision matches the payments, well-defined environmental service and contractual arrange- 
ments have to be available. However, the Raja Ampat entrance fee system lacks a directive (working manual or SOP) by which environmental services provided by sellers can be measured. But it is not unique in this. A review of 72 market schemes for biodiversity conservation revealed that an agreed upon measurement of biodiversity was absent and that the environmental service resulting from biodiversity conservation is mostly intangible [24]. If the wider definition of conditionality is applied, which is that any payment should encourage the provision of environmental services, the entrance fee system cannot be considered a PES arrangement, as there was and is no rule under this scheme that requires environmental service sellers to perform conservation or community livelihood improvement actions in order to be eligible to receive payment. A way forward would be to revise the directive for the distribution of community funds in such a way that communities are required to sign a contractual agreement with conservation oriented condition and actions, for example to replant mangroves, or to provide mooring buoys for liveaboard or speedboat, on submitting proposals for community funds. Mooring buoys will not only protect the surrounding coral reefs, as liveaboards and speedboats do not have to release anchors or keep drifting, but can also generate income for the village by applying a mooring fee.

\section{Acknowledgement}

This study was completed based on a scholarship from the Directorate General Higher Education of The Ministry of Research Technology and Higher Education of the Republic of Indonesia (Contract no:431/E4.4/K/2013).

\section{References}

[1] B. Adhikari, G. Boag, Designing payments for ecosystem services schemes: some considerations, Curr. Opin. Environ. Sustain. 5 (2013) 72-77. http://dx.doi.org/ 10.1016/j.cosust.2012.11.001.

[2] V.N. Agostini, H.S. Granth, J. Wilson, S. Mangubhai, C. Rotinsulu, N. Hidayat, A. Muljadi, Muhajir, M. Mongdong, A. Darmawan, L. Rumetna, M.V. Erdmann, H.P. Possingham, Achieving Fisheries and Conservation Objectives within Marine Protected Areas: zoning the Raja Ampat Network (No. 2/12), Indo-Pacific Division, The University of Queensland, Indonesia, 2012.

[3] N. Anyango-Van Zwieten, R. Van Der Duim, I.J. Visseren-Hamakers, Compensating for livestock killed by lions: payment for environmental services as a policy arrangement, Environ. Conserv. 42 (2015) 363-372. http://dx.doi.org/ 10.1017/S0376892915000090.

[4] A. Arman, Derap Langkah Kepemimpinan Marinda Dalam Membangun Raja Ampat, Nala Publishing House, 2014, pp. 2005-2015.

[5] R. Arnouts, Regional Nature Governance In The Netherlands: Four Decades of Governance Modes and Shifts in the Utrechtse Heuvelrug and MiddenBrabant (Ph.D. thesis), Wageningen University, Wageningen, 2010.

[6] C.M. Barr, I.A.P. Resosudarmo, A. Dermawan, J. McCarthy (Eds.), Decentralization of Forest Administration in Indonesia: Implications For Forest Sustainability, Economic Development, and Community Livelihoods, Center for International Forestry Research, Sindang Barang, Bogor, Indonesia, 2006.

[7] J.M. Bowker, H.K. Cordell, C.Y. Johnson, User fees for recreation services on public lands: a national assessment, 1999.

[8] J.Y. Chung, G.T. Kyle, J.F. Petrick, J.D. Absher, Fairness of prices, user fee policy and willingness to pay among visitors to a national forest, Tour Manag. 32 (2011) 1038-1046. http://dx.doi.org/10.1016/j.tourman.2010.08.016.

[9] T. Clements, A. John, K. Nielsen, D. An, S. Tan, E.J. Milner-Gulland, Payments for biodiversity conservation in the context of weak institutions: comparison of three programs from Cambodia, Ecol. Econ. 69 (2010) 1283-1291. http://dx.doi.org/ 10.1016/j.ecolecon.2009.11.010.

[10] E. Corbera, C.G. Soberanis, K. Brown, Institutional dimensions of payments for ecosystem services: an analysis of Mexico's carbon forestry programme, Ecol. Econ. 68 (2009) 743-761. http://dx.doi.org/10.1016/j.ecolecon.2008.06.008.

[11] E.M. De Santo, From paper parks to private conservation: the role of NGOs in adapting marine protected area strategies to climate change, J. Int. Wildl. Law Policy 15 (2012) 25-40.

[12] F. Depondt, E. Green, Diving user fees and the financial sustainability of marine protected areas: opportunities and impediments, Ocean Coast. Manag. 49 (2006) $188-202$.

[13] B. Fisher, R.K. Turner, P. Morling, Defining and classifying ecosystem services for decision making, Ecol. Econ. 68 (2009) 643-653. http://dx.doi.org/10.1016/ j.ecolecon.2008.09.014.

[14] Forest Trends (Organization), Katoomba Group (Eds.), 2010. Payments for ecosystem services: getting started in marine and coastal ecosystems: a primer. Forest Trends, Washington, D.C

[15] A.G. Gaman, A. Nebore, A. Djunaidi, D. Setywan, F. Urbasa, K. Wamafma, K. Thebu, L. Rumetna, M.P. Urbinas, M.V. Erdman, M. Fox, M. Mongdong, Muhajir,
M. Khazali, Mustaghfirin, N.I. Hidayat, Purwanto, S. Mangubhai, S. Sabonnama, Y. Maturbongs, Rencana pengelolaan taman pulau-pulau kecil daerah Raja Ampat. UPTD KKPD Kabupaten Raja Ampat, 2012.

[16] S. Gelcich, F. Amar, A. Valdebenito, J.C. Castilla, M. Fernandez, C. Godoy, D. Biggs, Financing marine protected areas through visitor fees: insights from tourists willingness to pay in Chile, Ambio 42 (2013) 975-984.

[17] G. Gios, D. Rizio, Payment for forest environmental services: a meta-analysis of successful elements, IFor - Biogeosci. For. 6 (2013) 141-149. http://dx.doi.org/ 10.3832/ifor0707-006.

[18] E. Gómez-Baggethun, R. de Groot, P.L. Lomas, C. Montes, The history of ecosystem services in economic theory and practice: from early notions to markets and payment schemes, Ecol. Econ. 69 (2010) 1209-1218. http://dx.doi.org/10.1016/ j.ecolecon.2009.11.007.

[19] L. Hein, D.C. Miller, R. de Groot, Payments for ecosystem services and the financing of global biodiversity conservation, Curr. Opin. Environ. Sustain. 5 (2013) 87-93. http://dx.doi.org/10.1016/j.cosust.2012.12.004.

[20] A.P. Hejnowicz, D.G. Raffaelli, M.A. Rudd, P.C.L. White, Evaluating the outcomes of payments for ecosystem services programmes using a capital asset framework, Ecosyst. Serv. 9 (2014) 83-97. http://dx.doi.org/10.1016/j.ecoser.2014.05.001.

[21] C.L. Huffard, J. Wilson, C. Hitipeuw, C. Rotinsulu, S. Mangubhai, M.V. Erdmann, W. Adnyana, P. Barber, J. Manuputty, M. Mondong, Ecosystem based management in the Bird's Head Seascape Indonesia: turning science into action. Ecosystem Based Management Program: Conservation International. Nat. Conserv. WWF Indones, 2012.

[22] R. Kumar, Research Methodology: A Step-by-step Guide For Beginners, SAGE, Los Angeles, 2011.

[23] M. Lamers, R. van der Duim, J. van Wijk, R. Nthiga, I.J. Visseren-Hamakers, Governing conservation tourism partnership in Kenya, Ann. Tour. Res. 48 (2014) $250-265$.

[24] N. Landell-Mills, I.T. Porras, others. Silver bullet or fools' gold?: a global review of markets for forest environmental services and their impact on the poor. International Institute for Environment and Development London, 2002.

[25] S.N. Larsen, C. Leisher, S. Mangubhai, A. Muljadi, R. Tapilatu, Report on a Coastal Rural Appraisal in Raja Ampat Regency, West Papua, Indonesia (No. 3/11), Asia Pacific Conservation Region Marine Program. The Nature Conservancy Indonesia Marine Program, Bali, 2011.

[26] S. Mangubhai, M.V. Erdmann, J.R. Wilson, C.L. Huffard, F. Ballamu, N.I. Hidayat, C. Hitipeuw, M.E. Lazuardi, Muhajir, D. Pada, G. Purba, C. Rotinsulu, L. Rumetna, K. Sumolang, W. Wen, Papuan bird's head seascape: emerging threats and challenges in the global center of marine biodiversity, Mar. Pollut. Bull. 64 (2012) 2279-2295. http://dx.doi.org/10.1016/j.marpolbul.2012.07.024.

[27] E. McLeod, B. Szuster, R. Salm, Sasi and marine conservation in Raja Ampat, Indonesia, Coast. Manag. 37 (2009) 656-676. http://dx.doi.org/10.1080/ 08920750903244143.

[28] S. Pagiola, Can payments for environmental services help protect coastal and marine areas, 2008.

[29] H. Peters, J.P. Hawkins, Access to marine parks: a comparative study in willingness to pay, Ocean Coast. Manag. 52 (2009) 219-228.

[30] Raja Ampat Regency. Atlas Sumberdaya Pesisir Kabupaten Raja Ampat. Raja Ampat Regency and Atlas Consortium of Coastal Resource of Raja Ampat, 2006

[31] K. Reid-Grant, M.G. Bhat, Financing marine protected areas in Jamaica: an exploratory study, Mar. Policy 33 (2009) 128-136.

[32] J. Ritchie, J. Lewis, Qualitative Research Practice; A Guide for Social Science Students and Researchers, Sage Publications, London, 2003.

[33] Rumetna Rudyanto, L. Setyawan, D. Prabowo, N. A, Dokumentasi proses dan pembelajaran pembentukan KKPD Raja Ampat dan pembentukan BLUD UPTD KKPD Raja Ampat, Nat. Conserv. (2016).

[34] A. Rylance, Estimating tourism's contribution to conservation area financing in Mozambique, Tour. Hosp. Res. (2016) (1467358415613119).

[35] S. Silvestri, L. Zaibet, M.Y. Said, S.C. Kifugo, Valuing ecosystem services for conservation and development purposes: a case study from Kenya, Environ. Sci. Policy 31 (2013) 23-33. http://dx.doi.org/10.1016/j.envsci.2013.03.008.

[36] S. Suyanto, B. Leimona, R.P. Permana, F.J. Chandler, et al., Review of Developments of Environmental Services Markets in Indonesia, World Agroforestry Centre (ICRAF), Bogor, Indonesia, 2016.

[37] M. Tafalas, Dampak Pengembangan Ekowisata Terhadap Kehidupan Sosial dan Ekonomi Masyarakat Lokal: studi Kasus Ekowisata Bahari Pulau Mansuar Kabupaten Raja Ampat (Master thesis), Bogor Agricultural University, Bogor, 2010.

[38] S.M. Thur, User fees as sustainable financing mechanisms for marine protected areas: an application to the Bonaire National Marine Park, Mar. Policy 34 (2010) 63-69.

[39] M.J. Tokede, D. Wiliam, Y. Widodo, gandhi, C. Imburi, J. Patriahadi, Mawa, M.C. Yufuai, The impact of special autonomy on Papua's forestry sector: empowering customary communities (Masyarakat Adat) in decentralizated forestry development in Manokwari district. Center for International Forestry Research, Bogor Barat, 2005.

[40] D.A. Varkey, C.H. Ainsworth, T.J. Pitcher, Y. Goram, R. Sumaila, Illegal, unreported and unregulated fisheries catch in Raja Ampat Regency, Eastern Indonesia, Mar. Policy 34 (2010) 228-236.

[41] A. Vatn, An institutional analysis of payments for environmental services, Ecol. Econ. 69 (2010) 1245-1252. http://dx.doi.org/10.1016/j.ecolecon.2009.11.018.

[42] P.A. Whitelaw, B.E.M. King, D. Tolkach, Protected areas, conservation and tourism - financing the sustainable dream, J. Sustain. Tour. 22 (2014) 584-603. http:// dx.doi.org/10.1080/09669582.2013.873445.

[43] S. Wunder, Revisiting the concept of payments for environmental services, Ecol Econ. 117 (2015) 234-243. http://dx.doi.org/10.1016/j.ecolecon.2014.08.016.

[44] S. Wunder, Payments for environmental services: Some nuts and bolts. Center for International Forestry Research, Bogor, 2005.

[45] R. Yin, Case Study Research; Design and Method (Second. ed.), SAGE Publications, Thousand Oaks, CA, 1994. 